\title{
Effectiveness of antibacterial extract of coriander seeds (coriandrum sativum L.) against staphylococcus aureus
}

\author{
Adam M. Hamudeng, Serliawati*
}

\section{Abstract}

Objective: Natural resources that can be used as natural antibacterial are coriandrum sativum $\mathrm{L}$. which contains linalool and phenol as antibacterial ingredients.

Material and Methods: Samples of bacteria were staphylococcus aureus taken from four children who had angular cheilitis. Extraction of coriandrum sativum L. using maceration method with ethanol solvent. Positive control group was given vancomycin, the treatment group was given extract of coriandrum sativum $\mathrm{L}$. concentrations of $0.1 \%, 0.2 \%, 0.4 \%, 0.8 \%, 1 \%, 2 \%$ and $4 \%$ were incubated 24 hours. Then the inhibitory zone measurements are carried out using a caliper.

Results: The study showed extract concentrations of $0.1 \%, 0.2 \%$ and $0.4 \%$ did not show any inhibition. The concentration of $0.8 \%$ inhibition

Keywords: Angular cheilitis, Staphylococcus aureus, Coriandrum sativum L

Cite This Article: Hamudeng AM, Serliawati. 2019. Effectiveness of antibacterial extract of coriander seeds (coriandrum sativum L.) against staphylococcus aureus. Journal of Dentomaxillofacial Science 4(2): 71-74 . D0l: 10.15562/jdmfs.v4i2.840

\section{Introduction}

Angular cheilitis is one of the diseases in the oral cavity that often occurs in children. ${ }^{1}$ Angular cheilitis in children is usually related to the sensitivity of children to certain contact agents such as toys, sunlight, the presence of allergies to drugs, and long-term use of antibiotics, and licking the corners of the lips and sucking fingers, and are most often the cause angular cheilitis in children is riboflavin deficiency. ${ }^{2}$ Angular cheilitis occurs due to the mucousation of the mucosa and skin at the corners of the mouth by saliva. ${ }^{3}$ With these conditions causes the accumulation of microorganisms. Microorganisms that can be found in angular cheilitis include candida albicans and staphylococcus aureus. ${ }^{4}$

Staphylococcus aureus is one of the grampositive bacteria that is kokus-shaped and has a diameter of $0.5-1.0 \mathrm{~mm}$, s. aureus bacteria are pathogenic bacteria, these bacteria play a role in toxic virulence, invasion, and have resistance to antibiotics. ${ }^{5}$ Almost everyone has had an infection by the bacteria s. aureus. ${ }^{6}$ Bacteria staphylococcus aureus are a component of flora in the mouth, a study shows that most infections that occur in the oral cavity are caused by the bacteria staphylococcus aureus. Infections that can be caused by s. aureus include angular cheilitis, endodontic infection, jaw zone was only seen in the second sample $(14.3 \mathrm{~mm})$. The first $1 \%$ sample concentration $(7.94 \mathrm{~mm})$, the second sample $(8.43 \mathrm{~mm})$, the third sample $(8.61 \mathrm{~mm})$ and the fourth sample $(7.77 \mathrm{~mm})$. The first $2 \%$ sample concentration $(8.18 \mathrm{~mm})$, the second sample $(8.61 \mathrm{~mm})$, the third sample $(8.64 \mathrm{~mm})$ and the fourth sample $(8.34 \mathrm{~mm})$. The first $4 \%$ sample concentration $(9.24 \mathrm{~mm})$, the second sample $(9.37$ $\mathrm{mm})$, the third sample $(8.81 \mathrm{~mm})$, and the fourth sample $(8.77 \mathrm{~mm})$. Vancomycin $(21.3 \mathrm{~mm}$ ) while the negative control did not show any inhibition, then the data was tested using the Kruskal Wallis and Mann Whitney Test $(p<0.05)$.

Conclusion: There is a difference in inhibitory power in each treatment and the $4 \%$ concentration that is most effective in inhibiting staphylococcus aureus.
*Correspondence to: Serliawati, Department of Pediatric, Faculty of Dentistry, Hasanuddin University, Makassar, Indonesia serli_shela@yahoo.com

Received: 5 August 2017 Revised: 26 February 2019 Accepted: 28 February 2019 Available Online 1 August 2019 osteomyelitis, parotitis and oral mucositis in the elderly. ${ }^{7}$

At this time antibiotic drugs for infections have been widely produced, but the drugs that are usually consumed are modern drugs that have the risk of side effects, and are not often resistant to bacteria. Therefore the use of drugs from nature can be used as alternative medicine. One of the natural resources that can be utilized in making antibacterial drugs is coriander seeds (coriandrum sativum L.).

Coriander seeds (coriandrum sativum L.) have an antibacterial effect, this is due to the presence of linalool from coriandrum sativum L. ${ }^{8}$ In addition to linalool coriandrum sativum L. also contains phenol compounds from its ethanol extract. ${ }^{9}$

\section{Material and Methods}

Type of research used was an experimental laboratory with Post Test Controlled Design. Making extracts and bacterial inhibitory tests was carried out in the Phytochemical and Microbiology Laboratory of Alauddin State Islamic University, Makassar. Coriander seed samples used are those obtained from traditional markets. Sampling of test bacteria was obtained from children who had angular cheilitis found on the side of the road or 
schools.

Coriander seed extract (coriandrum sativum L.) Was obtained using maceration method with $96 \%$ ethanol. Then the solvent was evaporated using a rotary evaporator so that thick extracts were obtained. After extraction, dilution was carried out with concentrations of $0.1 \%, 0.2 \%, 0.4 \%, 0.8 \%$, $1 \%, 2 \%$ and $4 \%$, while for positive and negative controls vancomycin and aquades were used.

Sample staphylococcus aureus: samples of bacteria were staphylococcus aureus taken from four children who had angular cheilitis using swab techniques. Then the swab bacteria were grown on Nutrient Agar (NA) medium and incubated for 24 hours, then the bacteria in the NA medium was transferred to a specific medium namely Mannitol Salt Agar (MSA), then the bacteria on the specific medium was transferred again to the liquid medium namely Nutrient Broth (NB) the suspension method will be carried out later using a micro pipette and then mixed with Nutrient Agar medium and poured into a petri dish.

\section{Results}

The results of the inhibition test of coriandrum sativum L. on staphylococcus aureus showed that extract coriandrum sativum L. effectively inhibited staphylococcus aureus at a concentration of $4 \%$ table 1.

In table 1 shows that at extract concentrations $0.1 \%, 0.2 \%$ and $0.4 \%$ did not show any inhibition in all samples. At the extract concentration of $0.8 \%$ the inhibition zone was only seen in the second sample with a diameter of $14.3 \mathrm{~mm}$. At $1 \%, 2 \%$ to $4 \%$ extract concentration showed the formation of inhibition zones in all samples with the highest inhibition zone at a concentration of $1 \%$ occurring in the third sample with a diameter inhibition zone of $8.61 \mathrm{~mm}$, at a concentration of $2 \%$ occurring in the third sample in diameter $8.64 \mathrm{~mm}$ inhibition zone,

Table 1 Inhibitory test results staphylococcus aureus

\begin{tabular}{lcccc}
\hline \multirow{2}{*}{ Concentration } & \multicolumn{4}{c}{ Diameter of inhibited zones per sample (mm) } \\
& Sample 1 & Sample 2 & Sample 3 & Sample 4 \\
\hline $0.1 \%$ & 0 & 0 & 0 & 0 \\
$0.2 \%$ & 0 & 0 & 0 & 0 \\
$0.4 \%$ & 0 & 0 & 0 & 0 \\
$0.8 \%$ & 0 & 14.3 & 0 & 0 \\
$1 \%$ & 7.94 & 8.43 & 8.61 & 7.77 \\
$2 \%$ & 8.18 & 8.61 & 8.64 & 8.34 \\
$4 \%$ & 9.24 & 9.37 & 8.81 & 8.77 \\
Positive & 21.3 & 21.3 & 21.3 & 21.3 \\
Negative controls & 0 & 0 & 0 & 0 \\
& & & & \\
\hline
\end{tabular}

while at $4 \%$ concentration the highest inhibition zone occurred in the second sample with a 9.37 $\mathrm{mm}$ inhibition zone diameter. In the positive control shows the formation of inhibition zones with a diameter width of $21.3 \mathrm{~mm}$ which is greater than that of all extract concentrations, whereas in the negative control there is no inhibition.

For minimum concentrations that can inhibit staphylococcus aureus in each sample can be seen in table 2.

In table 2 shows that Minimum Inhibitory Concentration the lowest (MIC) occurs in the second sample with a MIC of $0.8 \%$ which shows width of the inhibition zone $14.3 \mathrm{~mm}$. The results of the analysis of the research data can be seen in tables 3 and 4 . In table 3 shows that the data from each concentration shows a significant difference in inhibitory power seen from $\mathrm{p}<0.05$. Because the results were significant, then continued with the Post Hoc Test using Mann Whitney.

In table 4 shows there is a difference between the concentration of $0.8 \%$ with $0.1 \%, 0.2 \%, 0.4 \%$ but not significant ( $p>0.05)$. There is a significant difference between the concentrations of $1 \%, 2 \%$, $4 \%$ with $0.1 \%, 0.2 \%, 0.4 \%, 0.8 \%(\mathrm{p}<0.05)$. There is a difference between concentrations of $1 \%$, $2 \%$ and $4 \%$ but not significant ( $p>0.05)$, with a concentration of $4 \%$ which shows the highest difference between the two.

Table 2 Minimal Inhibitory Concentration (MIC) for each sample

\begin{tabular}{lcc}
\hline Samples & MIC $(\%)$ & Width of inhibition zone \\
\hline First sample & 1 & $7.94 \mathrm{~mm}$ \\
Second sample & 0.8 & $14.3 \mathrm{~mm}$ \\
Third sample & 1 & $8.61 \mathrm{~mm}$ \\
Fourth sample & 1 & $7.77 \mathrm{~mm}$ \\
\hline
\end{tabular}

Table 3 Results of data analysis with the Kruskal Wallis Test

\begin{tabular}{lllc}
\hline Concentration (\%) & Mean & SD & p value \\
\hline 0.1 & 0.00 & 0.00 & \\
& 0.2 & 0.00 & 0.00 \\
0.4 & 0.00 & 0.00 & \\
0.8 & 3.58 & 7.15 & 0.002 \\
1 & 8.19 & 0.40 & \\
2 & 8.44 & 0.22 & \\
4 & 9.05 & 0.30 & \\
Total & 4.18 & 4.70 & \\
\end{tabular}

\section{Discussion}

The results of the research obtained indicate that there is a difference in inhibition between one 
Table 4 Results of data analysis with the Mann Whitney Test

\begin{tabular}{llll}
\hline (I) Concentration (\%) & Mean difference (IJ) & Sig. \\
\hline 0.1 & 0.2 & 0.00 & 1.00 \\
& 0.4 & 0.00 & 1.00 \\
& 0.8 & -3.58 & 0.08 \\
& 1 & -8.19 & 0.00 \\
& 2 & -8.44 & 0.00 \\
& 4 & -9.05 & 0.00 \\
0.2 & 0.4 & 0.00 & 1.00 \\
& 0.8 & -3.58 & 0.08 \\
& 1 & -8.19 & 0.00 \\
& 2 & -8.44 & 0.00 \\
& 4 & -10.05 & 0.00 \\
0.4 & 0.8 & -3.50 & 0.08 \\
& 1 & -8.19 & 0.00 \\
& 2 & -8.44 & 0.00 \\
& 4 & -9.05 & 0.00 \\
0.8 & 1 & -4.61 & 0.03 \\
& 2 & -4.87 & 0.02 \\
& 4 & -5.47 & 0.01 \\
& 2 & -0.25 & 0.90 \\
2 & 4 & -0.86 & 0.66 \\
& 4 & -0.61 & 0.76 \\
\hline
\end{tabular}

concentration and the other concentration, and the concentration of extract that is most effective in inhibiting bacteria staphylococcus aureus is a concentration of $4 \%$.

The factors that influence the formation of inhibition zones include temperature and $\mathrm{pH}$ of the environment, the concentration of antibacterial compounds, the number of bacteria, the speed of diffusion of antibacterial compounds on agar media and the type of bacteria. For the $\mathrm{pH}$ factor using $\mathrm{pH} 7$ which is a neutral $\mathrm{pH}$, the temperature used is $37^{\circ} \mathrm{C}$, determining the number of bacteria using the suspension method, and the speed of diffusion of antibacterial compounds on the media so that each sample is the same, because all samples get the same treatment. The most likely factor that causes the formation of inhibitory zones in the four samples with the same concentration is the difference in strains of bacteria between one sample and another because the test bacteria were taken from four different children. ${ }^{10,11}$

A study conducted by Silva et al. ${ }^{8}$ using essential oils from coriandrum sativum L. was found to inhibit gram positive and gram negative bacteria, one of the gram-positive bacteria that can be inhibited is staphylococcus aureus SA08 with a minimum concentration of $0.4 \%$, staphylococcus aureus ATCC 25923 with a minimum concentration of $0.2 \%$, MRSA $08 / 08$ with a minimum concentration of $0.2 \%$, MRSA $08 / 08$ with a minimum concentration of $0.8 \% .{ }^{8}$ Based on the minimum amount of concentration, the results of this study are not much different from previous studies with minimal concentrations that can inhibit staphylococcus aureus, which is a concentration of $0.8 \%$ which occurs in the second sample.

A study of the inhibition of coriander seeds (coriandrum sativum L.) was also conducted by Yildiz. ${ }^{9}$ using essential oils and ethanol extract from coriandrum sativum L. It was found that there was inhibition in staphylococcus aureus ATCC 29213 at a minimum concentration of $31.3 \%[\mu \mathrm{g} / \mathrm{mL}]$ using essential oils from coriandrum sativum L., whereas using ethanol extract did not show any inhibition in the bacteria staphylococcus aureus. ${ }^{9}$ Based on the use of preparations, the coriandrum sativum L. results of this study are far different from the research conducted by Yildiz. ${ }^{9}$ because in this study using ethanol extract showed the presence of inhibition inbacteria staphylococcus aureus. While based on the amount of concentration, the results of this study are also much different from the research conducted by Yildiz. ${ }^{9}$ because in this study the minimum concentration that can inhibit bacteria staphylococcus aureus is $0.8 \%$ which occurs in the second sample, although it is compared with concentrations that do not produce inhibitory zones namely the concentration of $0.1 \%, 0.2 \%$ and $0.4 \%$ the difference is not significant.

The antibacterial effect of coriandrum sativum L. is due to the presence of linalool content. ${ }^{8}$ According to Park et al. ${ }^{14}$ the workings of linalool by damaging bacterial cell membranes, inhibiting bacterial enzymes and suppressing the translation of a particular gene product, inhibition of virulence from staphylococcus aureus in the form of enzymes released such as enzyme catalase, coagulase, hyaluronidase, nuclease and protease by the content of linalool from coriandrum sativum L. allows enzymatic work of staphylococcus aureus to be disrupted so that it will inhibit the growth of these bacteria. With the inhibition of the catalase enzyme from staphylococcus aureus causing free hydrogen peroxide which has an antibacterial effect still acceptable to the body, the coagulase enzyme that functions in catalyzing the conversion of fibrinogen to fibrin and coating the bacteria with fibrin makes it resistant to opsonization and phagocytosis becomes inhibited so that antibodies will be more easily phagocytosis of staphylococcus aureus, the hyaluronidase enzyme that functions to meet the nutritional needs of bacteria by degrading hyaluronic acid in connective tissue becomes inhibited so that the nutritional needs of bacteria will be disrupted and inhibit bacterial growth and can even cause bacterial cell death, as well as inhibited nuclease enzymes by linalool causing disruption of nutritional requirements 
from bacteria so that it will inhibit bacterial cell growth, whereas for protease enzymes which are inhibited by linalool causing ability bacterial invasion of tissues becomes blocked so that bacteria staphylococcus aureus can no longer spread to host tissues because bacteria staphylococcus aureus can no longer reduce human fibronectin. ${ }^{12-14}$ This is confirmed by research conducted by Yildiz. ${ }^{9}$ which states that coriandrum sativum L. contains antibacterial compounds, namely phenols from their ethanol extract. ${ }^{9}$ The phenol group can damage bacterial cell membranes, activate enzymes and denaturate proteins so that the cell wall is damaged due to decreased permeability. Changes in permeability of the cytoplasmic membrane of staphylococcus aureus by coriandrum sativum L. allow disruption of the transport of organic ions that enter into bacterial cells, causing inhibition of bacterial cell growth and even cell death. ${ }^{15,16}$

From the results of this study, it can be concluded that coriander seeds (coriandrum sativum L.) have an antibacterial effect on staphylococcus aureus so that they can be used in the treatment of angular cheilitis. This is also reinforced from research conducted by Yildiz. ${ }^{9}$ which showed that ethanol extract from coriandrum sativum L. can inhibit candida albicans. Where angular cheilitis occurs because of the accumulation of microorganisms including staphylococcus aureus and candida albicans. ${ }^{4}$

\section{Conclusion}

The results of the research obtained showed that the concentration of extract coriandrum sativum L. which was the most effective in inhibiting staphylococcus aureus was concentration $4 \%$.

\section{Acknowledgment}

We would like to thank Sukri for his valuable contribution as a mentor in the phytochemical and microbiology laboratory for this study.

\section{Conflict of Interest}

The authors report no conflict of interest.

\section{References}

1. Devani A. Angular cheilitis. Can Fam Physician 2007;53: 1022-1023

2. Fajriani. Management of angular cheilitis in children. J Dentomaxillofac Sci 2017;2: 1-3.

3. Hari, Anil. Angular cheilitis: review of etiology and clinical management. KDJ 1989;3: 229-231

4. Ohman SC, Jontell M. Treatment of angular cheilitis: the significance of microbial analysis, antimicrobial treatment, and interfering factors. Acta Odontol. Scand 1988;46: 267-272.

5. Karimela EJ, Ijong FG, Dien HA. Karakteristik staphylococcus aureus yang di isolasi dari ikan asap pinekuhe hasil olahan tradisional kabupaten sangihe. JPHPI 2017;20.

6. Lutpiatina L. Cemaran staphylococcus aureus dan pseudomonas aerogenosa pada steteskop di rumah sakit. J Teknologi Laboratorium 2017;6: 61-66.

7. Smith AJ, Jackson MS, Bagg J. The ecology of staphylococcus species in the oral cavity. J. Med. Microbiol 2001;50: 940-946.

8. Silva F, Ferreira S, Queiroz JA, et al. Coriander (coriandrum sativum L.) Essential oil: its antibacterial activity and mode of action evaluated by flow cytometry. J. Med. Microbiol 2011;60: 1479-1486.

9. Yildiz H. Chemical composition, antimicrobial, and antioxidant activities of essential oil and ethanol extract of coriandrum sativum L. leaves from turkey. Int J Food Prop 2016;19: 1593-1603.

10. Hidayat $\mathrm{S}$, Hanum F, Ismail AAK. Efektivitas daya hambat dan daya bunuh bakteri ulkus traumatikus pada mukosa mulut dengan berbagai konsentrasi propolis (trigona sp.). Edisi ke-1. Medali J;2: 79-84

11. Dewi R, Nurliana, Jamin F. Aktivitas antibakteri ekstrak protein crude isi saluran pencernaan ayam broiler yang diberi pakan tambahan pliek u. J. Med. Vet 2013;7: 54-56.

12. Diederichsen A. Coriander: coriandrum sativum L.. Bioversity International. 1996. p. 11-26.

13. Gundogan N, Devren A. Protease and lipase activity of staphylococcus aureus obtained from meat, chicken and meatball samples. GUJS 2010;23: 381-384.

14. Park SN, Lim YK, Freire MO, et al. Antimicrobial effect of linalool and $\alpha$-terpineol against periodontopathic and cariogenic bacteria. Anaerobe 2012;18: 369-372.

15. Purwantiningsih TI, Suranindyah YY, Widodo. Aktivitas senyawa fenol dalam buah mengkudu (morinda citrifolia) sebagai antibakteri alami untuk penghambatan bakteri penyebab mastitis. Bul. Peternak 2014;38: 59-64.

16. Srivastava RB, Thompson REM. Studies in the mechanism of action of phenol on escherichia coli cells. Br J Exp Pathol 1966;47: 315-323.

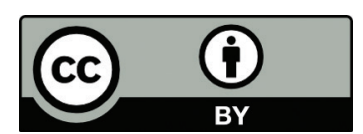

This work is licensed under a Creative Commons Attribution 